GRZEGORZ MAZUREK

Kielce University of Technology

e-mail: gmazurek@tu.kielce.pl

MAREK PSZCZOŁA

CEZARY SZYDŁOWSKI ${ }^{2}$

Gdańsk University of Technology

${ }^{1}$ e-mail: marek.pszczola@pg.edu.p

2e-mail: cezary.szydlowski@pg.edu.pl
Manuscript submitted 2018.07.27 - revised 2018.08.01 initially accepted for publication 2018.08.20, published in March 2019

\title{
NON-LINEAR MASTIC CHARACTERISTICS BASED ON THE MODIFIED MSCR (MULTIPLE STRESS CREEP RECOVERY) TEST
}

\section{NIELINIOWA CHARAKTERYSTYKA MASTYKSU NA PODSTAWIE ZMODYFIKOWANE METODY MSCR}

DOI: $10.30540 /$ sae-2019-002

\begin{abstract}
Mastic containing asphalt in its composition is an example of a viscoelastic material. It is an effective binder in asphalt. It consists of a filler $(<0.063 \mathrm{~mm})$ and asphalt mixed in the right proportions. Just like in asphalt, its response depends on the temperature level, the load and stress time. Changing the stress stiffness of the mastic affects the non-linear course of the stress-strain relationship. Modelling of the non-linear course of the mastic response for any stress history was performed using a single-integral Schapery equation. Two mastic composites made using filler to asphalt 2:1 ratio, was used in the tests. In addition, the contents of the filler, in one of the compositions, was enriched with hydrated lime in an amount of $15 \%$ in relation to the mass of the lime filler. It was found that the use of non-linear viscoelasticity model describes, in a comprehensive manner, the change in strain over time with different stress histories. In addition, hydrated lime reduced strains in the mastic compared to a composition consisting of limestone dust only.
\end{abstract}

Keywords: non-linear viscoelasticity, numerical modelling, MSCR test, mastic.

\section{Streszczenie}

Mastyks zawierajacy w swoim sktadzie asfalt jest przyktadem materiału lepkosprężystego. Stanowi on efektywne lepiszcze $w$ mieszance mineralno-asfaltowej. Składa się on z wypetniacza $(<0,063 \mathrm{~mm})$ oraz asfaltu wymieszanego w odpowiednich proporcjach. Tak samo jak w mma jego odpowiedź zależy od poziomu temperatury, czasu oddziaływania obciażenia. Zmiana sztywności mastyksu wywołana naprężeniem rzutuje na nieliniowy przebieg relacji naprężenia-odkształcenie. Modelowanie nieliniowego przebiegu reakcji mastyksu dla dowolnej historii naprężenia zostało wykonane przy użyciu jednocatkowego równania Schapery'ego. W badaniach wykorzystano dwie kompozycje mastyksu sporządzonego przy proporcji wypetniacza do asfaltu wynoszacego 2:1. Ponadto skład wypetniacza został w jednej z kompozycji wzbogacony o wapno hydratyzowane $w$ ilości $15 \%$ w stosunku do masy wypetniacza wapiennego. Stwierdzono, że zastosowanie modelu nieliniowej lepkosprężystości w sposób kompleksowy opisuje zmianę odkształcenia w czasie przy różnej historii występowania naprężna. Ponadto wapno hydratyzowane korzystnie ograniczyło deformacje $w$ mastyksie $w$ stosunku do kompozycji składającej się wyłącznie z maczki wapiennej.

Slowa kluczowe: non-linear viscoelasticity, numerical modelling, MSCR test, mastic.

\section{INTRODUCTION}

Road materials containing asphalt in their composition belong to viscoelastic materials (real bodies). In the design of new road structures, asphalt composites are treated as materials corresponding

\section{WPROWADZENIE}

Materiały drogowe zawierające w swoim składzie asfalt należą do materiałów lepkosprężystych (ciała rzeczywiste). W projektowaniu nowych konstrukcji nawierzchni drogowych kompozyty mineralno-as- 
to the elastic physical model [1]. It is a model that maintains a linear stress-strain relationship [2]. Unfortunately, the inability to include the time causes that it does not reflect the phenomenon of relaxation or creep that takes place in any structure of a flexible road surface [3]. Therefore, its use is limited to cases in which the road structure is briefly loaded for about $0.02 \mathrm{~s}$ or exposed to low temperature below $+13^{\circ} \mathrm{C}$. The viscoelastic model is a much better tool that reflects the behaviour of bituminous road materials. The viscoelastic model allows for the time of stress interaction, however, usually in most applications it is limited to the linear viscoelasticity range (LVE) [4-6], where the $\sigma \rightarrow \varepsilon$ relationship is linear. This allows structuring curves of the leading viscoplastic functions [7]. Nevertheless, in reality the case of linear viscoelasticity is a special case of non-linear course of the $\sigma \rightarrow \varepsilon$ relationship [8], because the bituminous road materials experience momentary creep phenomena at the moment of the applied stress [9]. In addition, the range of viscoelasticity may change if the rate of stress increment is low [10]. Practice indicates that permanent strains are created in the material even in the LVE range, which suggest the non-linearity of the $\sigma \rightarrow \varepsilon$ relationship $[11,12]$. Therefore, the application of the non-linear viscoelastic model is the most rational approach to the nature of bituminous road materials, including mastics. The record in the form of a singleintegral relationship allows the implementation of parameters, such as time, temperature and stress to the description of the $\sigma \rightarrow \varepsilon$ relationship, which basically play the most important role in the deformability evaluation of the mastic as well as other asphalt composites. Due to the fact that the mastic is an effective binder in an asphalt, its rheological changes will significantly reflect the deformability of asphalt.

\section{MATERIALS AND METHODS}

\subsection{Mastic}

Mastic is a mixture of asphalt and mineral filler $(<0.063 \mathrm{~mm})$. It is an effective binder in asphalt and determines its rheological properties [13]. The 50/70 road asphalt was used in the tests. To make a mastic, reference lime filler (LM) and mixed filler were used, produced from the combination of hydrated lime (HL) and lime filler in the proportion (HL/LM) faltowe traktowane są jako materiały odpowiadające sprężystemu modelowi fizycznemu [1]. Jest to model który zachowuje liniową relację naprężenie-odkształcenie [2]. Niestety brak możliwości uwzględnienia czasu powoduje, że nie odwzoruje on zjawiska relaksacji ani też pełzania, które ma miejsce w każdej konstrukcji podatnej nawierzchni drogowej [3].W związku z tym jego stosowanie jest ograniczone do przypadków w których konstrukcja nawierzchni jest obciążona przez krótki czas około $0,02 \mathrm{~s}$ w niskiej temperaturze poniżej $+13^{\circ} \mathrm{C}$. Znacznie lepszym narzędziem, które odzwierciedla zachowania bitumicznych materiałów drogowych jest model lepkosprężysty. Model lepkosprężysty uwzględnia czas oddziaływania naprężenia, jednak zwykle w większości zastosowań jest ograniczony do zakresu liniowej lepkosprężystości (LVE) [4-6], gdzie relacja $\sigma \rightarrow \varepsilon$ jest liniowa. Pozwala to na konstruowanie krzywych wiodących funkcji lepkosprężystości [7]. Niemniej jednak w rzeczywistości przypadek liniowej lepkosprężystości jest szczególnym przypadkiem nieliniowego przebiegu relacji $\sigma \rightarrow \varepsilon$ [8], gdyż bitumiczne materiały drogowe $\mathrm{w}$ momencie przyłożonego naprężenia doznają natychmiastowego zjawiska pełzania [9]. Ponadto zakres relacji $\sigma-\varepsilon$ odpowiadający liniowej lepkosprężystości może ulec zmianie, jeśli szybkość przyrostu naprężenia będzie mała [10]. Praktyka wskazuje, że nawet $\mathrm{w}$ zakresie LVE $\mathrm{w}$ materiale powstają trwałe odkształcenia co sugeruje nieliniowość relacji $\sigma \rightarrow \varepsilon[11,12]$. W związku z tym zastosowanie nieliniowego modelu lepkosprężystości jest najbardziej racjonalnym ujęciem natury bitumicznych materiałów drogowych, w tym również mastyksu. Zapis w postaci relacji jednocałkowej pozwala na implementację do opisu relacji $\sigma \rightarrow \varepsilon$, takich parametrów jak: czas, temperatura oraz naprężenie, które zasadniczo odgrywają najistotniejszą rolę w ocenie odkształcalności mastyksu jak i innych kompozytów mineralno-asfaltowych. $\mathrm{Z}$ faktu, że mastyks stanowi efektywne lepiszcze w mieszance mineralno-asfaltowej, jego zmiany reologiczne będą bardzo istotnie odzwierciedlały odkształcalność mieszanek mineralno-asfaltowych.

\section{MATERIAKY I METODY}

\subsection{Mastyks}

Mastyks jest to mieszanina asfaltu oraz wypełniacza mineralnego $(<0,063 \mathrm{~mm})$. Stanowi on efektywne lepiszcze w mieszance mineralno-asfaltowej i decyduje o jej właściwościach reologicznych [13]. W badaniach został wykorzystany asfalt drogowy 50/70. Do sporządzenia mastyksu wykorzystano referencyjny wypełniacz wapienny (LM) oraz wypeł- 
equal to $0.15(\mathrm{~m} / \mathrm{m})$, in accordance with the recommendation given in the work [14]. The asphalt and filler samples were heated to a temperature of $155^{\circ} \mathrm{C}$ and such temperature was maintained for 30 minutes. The next step was mixing asphalt and various filler compositions at a constant temperature and at $400 \mathrm{rpm}$. After mixing, the mastic samples to be tested were preconditioned at $5^{\circ} \mathrm{C}$ until the test. A detailed list of results set by EN 14043 are shown in Table 1.

\begin{tabular}{|c|c|c|c|c|}
\hline \multirow{3}{*}{ Parameter } & \multirow{3}{*}{ Standard } & \multirow{3}{*}{ Uom } & \multicolumn{2}{|c|}{ Component/mixture } \\
\hline & & & LS & HL/LS \\
\hline & & & & $0.3(\mathrm{~m} / \mathrm{m})$ \\
\hline Rigden voids & EN 1097-4 & $\%$ & 35.12 & 41.13 \\
\hline $\begin{array}{l}\text { Temperature increment } \\
\text { of ring and ball }\end{array}$ & EN 13179-1 & ${ }^{\circ} \mathrm{C}$ & 11.08 & 18.51 \\
\hline $\begin{array}{l}\text { Stone density of the filler } \\
\text { composition }\end{array}$ & EN 1097-7 & $\mathrm{Mg} / \mathrm{m}^{3}$ & 2.71 & 2.55 \\
\hline
\end{tabular}

It should also be remembered to avoid excessive amount of hydrated lime to the volume of lime filler due to the intense increase of mastic stiffness and the reduction of significant workability of asphalt. According to researchers [15] the value $V_{\mathrm{fb}}$ (volume of concentrated filler) for dusts from the dust extraction system should be about $60 \%$ as it causes excessive stiffening of the mastic. Considering the data contained in the Leuseur's work [14] the weight ratio of the filler to asphalt should not exceed 2.5:1. Following these guidelines, it was found that the 2:1 ratio of asphalt to filler would be the most appropriate for comparison purposes, irrespective of the amount of hydrated lime in the lime filler. Assumptions of the adopted research plan are presented in Table 2.

\begin{tabular}{|c|c|c|c|c|c|}
\hline $\mathbf{H L} / \mathbf{L}$ & $\mathbf{F} / \mathbf{B}$ & $\begin{array}{c}\mathbf{F} / \mathbf{B} \\
\text { density }\end{array}$ & $\mathbf{V}_{\text {mix.filler }}$ & $\mathbf{V}_{\text {bit }}$ & $\mathbf{V}_{\text {fb }}$ \\
\hline $\mathbf{( w / w )}$ & $\mathbf{( w / w )}$ & $\mathbf{M g} / \mathbf{m}^{3}$ & $\%(\mathbf{v} / \mathbf{v})$ & $\%(\mathbf{v} / \mathbf{v})$ & $\%$ \\
\hline 0.00 & 0.00 & 1.03 & - & - & - \\
\hline 0.00 & 2.00 & 1.75 & 43.03 & 56.97 & 66.33 \\
\hline 0.15 & 2.00 & 1.72 & 43.75 & 56.25 & 71.76 \\
\hline
\end{tabular}

Table 2. Experimental research plan and appropriate mastic compositions

Tabela 2. Plan badań eksperymentalnych oraz odpowiednie kompozycje mastyksu

niacz mieszany, który powstał w wyniku połączenia wapna hydratyzowanego (HL) oraz wypełniacza wapiennego w proporcji (HL/LM) równej $0,15(\mathrm{~m} / \mathrm{m})$, sugerując się zaleceniami podanymi $\mathrm{w}$ pracy [14] Próbki asfaltu oraz wypełniacza zostały rozgrzane do temperatury $155^{\circ} \mathrm{C}$ i utrzymywane w niej przez 30 minut. Kolejnym etapem było wymieszanie asfaltu i różnych kompozycji wypełniacza w stałej temperaturze przy $400 \mathrm{obr} / \mathrm{min}$. Po wymieszaniu przeznaczone do badania próbki mastyksu były kondycjonowane w temperaturze $5^{\circ} \mathrm{C}$ do czasu badania. Szczegółowe zestawienie wybranych właściwości wypełniacza zgodnie z EN 13043, przedstawiono w tabeli 1.

Table 1. Selected physical parameters of the mixed filler according to PN EN 14043

Tabela 1. Wybrane parametry fizyczne wypetniacza mieszanego wg PN EN 13043

Należy również pamiętać o unikaniu nadmiernej ilości wapna hydratyzowanego w stosunku do objętości wypełniacza wapiennego zuwagi na intensywny wzrost sztywności mastyksu oraz istotne zmniejszenie urabialności mieszanki mineralno-asfaltowej. Według badaczy [15] wartość $V_{\mathrm{fb}}$ (objętość zagęszczonego wypełniacza) dla pyłów z systemu odpylania powinna wynosić około $60 \%$, ponieważ wywołuje nadmierne usztywnienie mastyksu. Biorąc pod uwagę informacje zawarte w pracy Leuseur [14], stosunek wagowy wypełniacza do asfaltu nie powinien być większy niż 2,5:1. Sugerując się tymi zaleceniami ustalono, że do celów porównawczych najbardziej odpowiednia będzie proporcja asfaltu do wypełniacza wynosząca 2:1, bez względu na ilość wapna hydratyzowanego w składzie wypełniacza wapiennego. Założenia przyjętego planu badań przedstawiono w tabeli 2. 
The reference asphalt was the first composition. F/B refers to the filler/bitumen weight ratio. HL/L means the percentage of hydrated lime in the total mass of the filler.

\subsection{Modified MSCR test}

This test allows assessing the compliance and recovery of binder in simulated load conditions, close to real conditions in the linear and non-linear viscoelasticity range. Normally, the MSCR test is performed on the basis of PN-EN 16659: 2016-02 and AASHTO TP70. This test is performed using a rheometer equipped with a parallel plate set-up in accordance with EN 14770: 2012 in a controlled stress system. The compliance assessment of the binder is performed for shear stress of $100 \mathrm{kPa}$ and $3200 \mathrm{~Pa}$ applied for 1 second, and then the measurement of elastic recovery of asphalt for 9 seconds, at the asphalt temperature of $60^{\circ} \mathrm{C}$, is performed. The entire cycle for one stress range lasts 100 seconds. Consequently, the compliance value $J_{\text {nr }}$ (irreversible part of the strain divided by the applied stress) and elastic recovery ER\% are determined.

The standard MSCR test was modified by an extra shear stress sequence of $6400 \mathrm{~Pa}$. In addition, the number of load cycles was modified. The experiment involved three load cycles for three stress levels, namely: $100 \mathrm{~Pa}, 3200 \mathrm{~Pa}$ and $6400 \mathrm{~Pa}$. As a result, the entire test lasted 90 seconds. All tests were performed at $60^{\circ} \mathrm{C}$. According to researchers [11], the application of the first three load cycles correctly represents the strain change over time.

\section{NON-LINEAR SCHAPERY MODEL}

\subsection{Description of the non-linear Schapery model}

The theory proposed by Schapery is one of the most commonly used methods, mainly in polymers, describing the non-linear nature of viscoelasticity. It was determined basing on thermodynamics of irreversible processes $[10,16,17]$. Performing certain transformations in relation to the constant temperature at the uniaxial state of stress induced by the independent variable $\sigma_{0}$, the representation of the strain change (creep test), using the single-integral relationship, has the following formula (1):
Pierwszą kompozycję stanowił asfalt referencyjny. Oznaczenie F/B odnosi się do stosunku wagowego wypełniacz/asfalt. Oznaczenie HL/L oznacza udział procentowy wapna hydratyzowanego w całkowitej masie wypełniacza.

\subsection{Zmodyfikowana metoda MSCR}

Metoda MSCR pozwala ocenić podatność oraz nawrót lepiszcza w symulowanych warunkach obciążenia zbliżonych do rzeczywistych w liniowym i nieliniowym zakresie lepkosprężystości. Klasycznie badanie MSCR wykonuje się na podstawie PN-EN 16659:2016-02 oraz AASHTO TP70. Badanie to wykonuje się za pomocą reometru wyposażonego $\mathrm{w}$ zestaw płytka-płytka zgodnie z normą EN 14770:2012 w układzie kontrolowanego naprężenia. Ocenę podatności lepiszcza wykonuje się dla naprężenia ścinającego $100 \mathrm{~Pa}$ oraz 3200 Pa przykładanego przez 1 sekundę, a następnie wykonywany jest pomiar nawrotu sprężystego asfaltu przez 9 sekund $w$ temperaturze asfaltu $60^{\circ} \mathrm{C}$. Cały cykl dla jednego zakresu naprężenia wynosi 100 sekund. Wykonując niniejsze badanie według MSCR można określić podatność $J_{\mathrm{nr}}$ (nieodwracalna cześć odkształcenia podzielona przez przyłożone naprężenie) oraz nawrotu sprężystego ER\%.

W niniejszym badaniu zastosowano modyfikację klasycznego badania MSCR o dodatkową sekwencję naprężenia ścinającego równego $6400 \mathrm{~Pa}$. Ponadto zastosowano modyfikację liczby cykli obciążenia. W eksperymencie zastosowano trzy cykle obciążenia dla trzech poziomów naprężenia, a mianowicie: 100 $\mathrm{Pa}, 3200 \mathrm{~Pa}$ oraz $6400 \mathrm{~Pa}$. W rezultacie całe badanie trwało 90 sekund. Wszystkie badania wykonano w temperaturze $60^{\circ} \mathrm{C}$. Według badaczy [11] zastosowanie trzech pierwszych cykli obciążenia poprawnie reprezentuje relację zmiany odkształcenia w czasie.

\section{NIELINIOWY MODEL SCHAPERY'EGO}

\subsection{Opis nieliniowego modelu Schapery'ego}

Teoria zaproponowana przez Schapery'ego jest jedną z najczęściej stosowanych teorii, głównie wykorzystywana do oceny nieliniowego zachowania pewnych polimerów, opisujących nieliniowy charakter lepkosprężystości. Została ona sformułowana na podstawie zasad termodynamiki procesów nieodwracalnych $[10,16,17]$. Wykonując pewne przekształcenia względem stałej temperatury przy jednoosiowym stanie naprężenia wywołanego niezależną zmienną $\sigma_{0}$ reprezentacja zmiany odkształcenia (próba pełzania) za pomocą relacji jednocałkowej ma postać: 


$$
\begin{gathered}
\gamma(t)=g_{0} J_{0} \sigma(t)+ \\
+\sigma(t) g_{1} \int_{0}^{t} \Delta J\left(\psi^{t}-\psi^{\tau}\right)\left\{\frac{d\left(g_{2} \sigma(\tau)\right)}{d \tau}\right\} d \tau+ \\
+\gamma_{\text {irrec }}(t)
\end{gathered}
$$

where: $J_{0}$-instantaneous creep compliance, $\Delta J$ - creep compliance dependant on time, $g_{0}, g_{1}, g_{2}$ - parameters in the stress function modelling the non-linear course of the $\sigma \rightarrow \varepsilon$ relationship, $\gamma_{\text {irrec }}(t)-$ level of irreversible strains. The reduced time in formula (1) adopts the following form:

$$
\psi^{t}=\int_{0}^{t} \frac{d t^{\prime}}{a_{\sigma}\left[\sigma\left(t^{\prime}\right)\right]} \text { and } \psi^{\tau}=\int_{0}^{t} \frac{d \tau}{a_{\sigma}[\sigma(\tau)]}
$$

Material parameters are stress-dependant $g_{0}, g_{1}, g_{2}$ parameters. They reflect the relationship of the third and fourth order of the Gibbs free energy from stress. The parameter $a_{\sigma}$, also depending on the stress level, is in fact a horizontal shift coefficient on the time scale [10].

The equation (1) represents the creep course in which separation follows into the part independent of time $J_{0}$ and time-dependent $\Delta J$. The fundamental issue is to define the sub-integral creep function. Exponentiation has the simplest form [10]. The applied function allows obtaining reliable results at the expense of lowering estimation precision within a long period of time. The function derived from the group of physical models of generalized viscoelasticities is much more beneficial. Therefore, a generalized Kelvin-Voigt model with an additional Hooke element (GK-E) was proposed. It allows for the representation of material in the range in which the part of the strain is constant and independent of time (short load time) $J_{0}$. A graphic representation of the adopted model is shown in Figure 1.

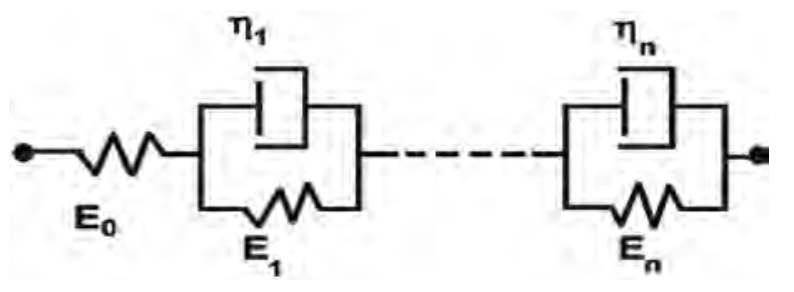

$$
\begin{gathered}
\gamma(t)=g_{0} J_{0} \sigma(t)+ \\
+\sigma(t) g_{1} \int_{0}^{t} \Delta J\left(\psi^{t}-\psi^{\tau}\right)\left\{\frac{d\left(g_{2} \sigma(\tau)\right)}{d \tau}\right\} d \tau+ \\
+\gamma_{\text {irrec }}(t)
\end{gathered}
$$

gdzie: $J_{0}$ - podatność pełzania natychmiastowa, $\Delta J-$ podatność pełzania zależna od czasu, $g_{0}, g_{1}, g_{2}$ - parametry materiałowe zależne od historii przyłożonego naprężenia $\mathrm{w}$ czasie modelujące nieliniowy przebieg relacji $\sigma \rightarrow \varepsilon, \gamma_{\text {irrec }}(t)-$ poziom odkształceń nieodwracalnych. Czas zredukowany we wzorze (1) ma następującą postać:

$$
\psi^{t}=\int_{0}^{t} \frac{d t^{\prime}}{a_{\sigma}\left[\sigma\left(t^{\prime}\right)\right]} \text { oraz } \psi^{\tau}=\int_{0}^{t} \frac{d \tau}{a_{\sigma}[\sigma(\tau)]}
$$

Zasadniczą rolą parametrów materiałowe $g_{0}, g_{1}, g_{2}$ jest odzwierciedlenie efektu nieliniowości wywołaną poziomem przyłożonego obciążenia do materiału. Odzwierciedlają one relację trzeciego i czwartego rzędu energii swobodnej Gibbsa od naprężenia. Parametr $a_{\sigma}$, również zależny od poziomu naprężenia, jest $\mathrm{w}$ istocie współczynnikiem przesunięcia poziomego na skali czasu [10], spełniający tę samą rolę co współczynnik przesunięcia temperaturowego wykorzystywany w zasadzie superpozycji czas-temperatura.

Równanie (1) reprezentuje przebieg pełzania, w którym występuje rozdzielenie na część niezależną od czasu $J_{0}$ oraz zależną od czasu $\Delta J$. Podstawową kwestią jest określenie podcałkowej funkcji pełzania. Najprostszą postać posiada funkcja potęgowa [10]. Jest to funkcja, która oferuje łatwą implementację i miarodajne wyniki jednak poświęca ona precyzję analiz wykonanych w szerokim spektrum czasu. Znacznie korzystniejszą jest funkcja pochodząca $\mathrm{z}$ grupy fizycznych modeli uogólnionych lepkosprężystości. W związku z tym zaproponowano postać uogólnionego modelu Kelvina-Voigta $\mathrm{z}$ dodatkowym elementem Hooke'a (GKE). Pozwala on na reprezentację materiału w zakresie, w którym część odkształcenia jest stała i niezależna od czasu (krótki czas obciążenia) $J_{0}$. Graficzną reprezentację przyjętego modelu przedstawiono na rysunku 1.

Fig. 1 Generalized Kelvin-Voigt model adopted with an additional Hooke element (GK-H)

Rys. 1. Przyjęty uogólniony model Kelvina-Voigta z dodatkowym elementem Hooke'a (GK-H) 
Therefore, the overall form of the creep function (1) changing the integral as the sum of the Prony series elements is as follows:

$$
J\left(\psi^{t}\right)=J_{0}+\sum_{i=1}^{n} J_{i}\left[1-e^{\left(-\lambda_{i} \psi^{t}\right)}\right]
$$

where: $J_{i}-\mathrm{i}$-th element of compliance representing the $\mathrm{i}$-th element of the Prone series (Kelvin-Voigt element), $\lambda_{\mathrm{i}}-\mathrm{i}$-th element of the time of retardation in relation to i-compliance. Finally, the course of the non-linear strain of the Schapery model in the creep test is the following:

$$
\begin{gathered}
\text { for load time } \\
\gamma_{c r}(t)=g_{0} J_{0} \sigma+ \\
+\sigma g_{1} g_{2} \sum_{i=1}^{n} J_{i}\left[1-e^{\left(-\lambda_{i} \frac{t}{a_{\sigma}}\right)}\right]+\gamma_{\text {irrec }}(t) \\
\text { for relief time } \\
\gamma_{r e}(t)=\sigma g_{2} \sum_{i=1}^{n} J_{i}\left[1-e^{\left(-\lambda_{i} \frac{t}{a_{\sigma}}\right)}\right]- \\
\sigma g_{2} \sum_{i=1}^{n} J_{i}\left[1-e^{\left(\lambda_{i} \frac{t-t a}{a_{\sigma}}\right)}\right]+\gamma_{\text {irrec }}\left(t_{a}\right)
\end{gathered}
$$

where: $t_{\mathrm{a}}$ - beginning of relief time, $\mathrm{t}$ - duration of the creep test cycle with relief.

\subsection{Determining the parameters of the model}

Parameters of the non-linear Schapery model, i.e. material $g_{0}, g_{1}, g_{2}$ and $a_{\sigma}$, determined based on the analysis of the return stage, which reflects the pure course of the elastic recovery. It should be remembered that the low-stress test, i.e. in the LVE range, should be performed as first to determine nonlinear parameters. Therefore, to determine the Prony series parameters in the LVE range, a stress of 100 $\mathrm{Pa}$ was applied, taking into account the change in strain in the third load cycle. Total elastic strain in the relief phase $\Delta \varepsilon_{r e}$ for the first cycle in the LVE range determines the relationship:

$$
\begin{gathered}
\Delta \gamma_{r e 1}(t)=\gamma_{c r}(t)-\gamma_{c r}(t)=g_{0} J_{0} \sigma_{1} \\
+\sigma_{1}\left\{g_{1} g_{2} \sum_{i=1}^{n} J_{i}\left[1-e^{\left(-\lambda_{i} \frac{t_{a}}{a_{\sigma}}\right)}\right]-g_{2} \sum_{i=1}^{n} J_{i}\left[1-e^{\left(\lambda_{i} \frac{t}{a_{\sigma}}\right)}\right]\right. \\
\left.+g_{2} \sum_{i=1}^{n} J_{i}\left[1-e^{\left(\lambda_{i} \frac{t-t_{a}}{a_{\sigma}}\right)}\right]\right\}
\end{gathered}
$$

W związku z tym postać całkowita funkcji pełzania (1) zamieniając całkę jako sumę elementów Prony series jest następująca:

$$
J\left(\psi^{t}\right)=J_{0}+\sum_{i=1}^{n} J_{i}\left[1-e^{\left(-\lambda_{i} \psi^{t}\right)}\right]
$$

gdzie: $J_{\mathrm{i}}$ - i-ta podatność reprezentująca i-ty element serii Prony'ego (element Kelvina-Voigta), $\lambda_{i}-i$-ty czas retardacji względem i-tej podatności. Ostatecznie przebieg odkształcenia nieliniowego modelu Schapery'ego w próbie pełzania z powrotem jest następujący:

$$
\begin{gathered}
\text { dla czasu obciążenia } \\
\gamma_{c r}(t)=g_{0} J_{0} \sigma+ \\
+\sigma g_{1} g_{2} \sum_{i=1}^{n} J_{i}\left[1-e^{\left(-\lambda_{i} \frac{t}{a_{\sigma}}\right)}\right]+\gamma_{\text {irrec }}(t)
\end{gathered}
$$

dla czasu odciążenia

$$
\begin{aligned}
& \gamma_{r e}(t)=\sigma g_{2} \sum_{i=1}^{n} J_{i}\left[1-e^{\left(-\lambda_{i} \frac{t}{a_{\sigma}}\right)}\right]- \\
& \sigma g_{2} \sum_{i=1}^{n} J_{i}\left[1-e^{\left(\lambda_{i} \frac{t-t a}{a_{\sigma}}\right)}\right]+\gamma_{\text {irrec }}\left(t_{a}\right)
\end{aligned}
$$

gdzie: $t_{\mathrm{a}}$ - początek czasu odciążenia, $t$ - czas trwania cyklu próby pełzania $\mathrm{z}$ odciążeniem.

\subsection{Wyznaczenie parametrów modelu}

Parametry nieliniowego modelu Schapery'ego, czyli materiałowe $g_{0}, g_{1}, g_{2}$ oraz $a_{\sigma}$, wyznaczono w oparciu o analizę etapu powrotu, która odzwierciedla czysty przebieg nawrotu sprężystego. Należy pamiętać, że do wyznaczenia parametrów nieliniowych trzeba wykonać, jako pierwsze, badanie w zakresie małych naprężeń, czyli w zakresie LVE. W związku z tym do wyznaczeniu parametrów Prony series w zakresie LVE zastosowano naprężenie $100 \mathrm{~Pa}$, biorąc pod uwagę zmianę odkształcenia w trzecim cyklu obciążenia. Całkowite odkształcenie sprężyste $\mathrm{w}$ fazie odciążenia $\Delta \varepsilon_{\text {re }}$ dla 1 cyklu w zakresie LVE określa zależność:

$$
\begin{gathered}
\Delta \gamma_{r e 1}(t)=\gamma_{c r}(t)-\gamma_{c r}(t)=g_{0} J_{0} \sigma_{1} \\
+\sigma_{1}\left\{g_{1} g_{2} \sum_{i=1}^{n} J_{i}\left[1-e^{\left(-\lambda_{i} \frac{t_{a}}{a_{\sigma}}\right)}\right]-g_{2} \sum_{i=1}^{n} J_{i}\left[1-e^{\left(\lambda_{i} \frac{t}{a_{\sigma}}\right)}\right]\right. \\
\left.+g_{2} \sum_{i=1}^{n} J_{i}\left[1-e^{\left(\lambda_{i} \frac{t-t_{a}}{a_{\sigma}}\right)}\right]\right\}
\end{gathered}
$$


Using the relationship (5), the parameters of the Prony series in the GK-E model such as $J_{0}, J_{\text {n }}$ and $\lambda_{\mathrm{n}}(n=1,2,3, \ldots, n)$ were determined. Basing on this information, a second 3200 Pa load cycle was performed to determine non-linear parameters $g_{0}(3200 \mathrm{~Pa}), g_{1}(3200 \mathrm{~Pa})$, and $g_{\sigma}(3200 \mathrm{~Pa})$ in relation to the course of strain in the third load cycle. Then the strain course was recorded for the third load cycle at a constant stress of $6400 \mathrm{~Pa}$. The value of non-linear parameters was also determined for this stress. Increasing the number of stress levels allows for their functional binding and allows for a later forecast of the strain course for any level of shear stress. The entire load process is shown schematically below i Figure 1:
Wykorzystując zależność (5) zostały wyznaczone parametry szeregu Prony w modelu GK-E takie jak $J_{0}, J_{\mathrm{n}}$ oraz $\lambda_{\mathrm{n}}(\mathrm{n}=1,2,3, \ldots, \mathrm{n})$. W oparciu o tą informację wykonano drugi cykl obciążenia dla naprężenia $3200 \mathrm{~Pa}$ w celu wyznaczenia parametrów nieliniowej lepkosprężystości: $g_{0}(3200 \mathrm{~Pa}), g_{1}(3200 \mathrm{~Pa})$ oraz $g_{\sigma}(3200 \mathrm{~Pa})$ względem przebiegu odkształcenia w trzecim cyklu obciążenia. Następnie zarejestrowano przebieg odkształcenia dla trzeciego cyklu obciążenia przy stałym naprężeniu $6400 \mathrm{~Pa}$. Dla tego naprężenia wyznaczono również wartość nieliniowych parametrów. Zwiększenie liczby poziomów naprężenia pozwala na funkcyjne ich związanie i umożliwia późniejszą prognozę przebiegu odkształcenia dla dowolnego poziomu naprężenia ścinającego. Cały proces obciążenia przedstawiono schematycznie na rysunku 2:

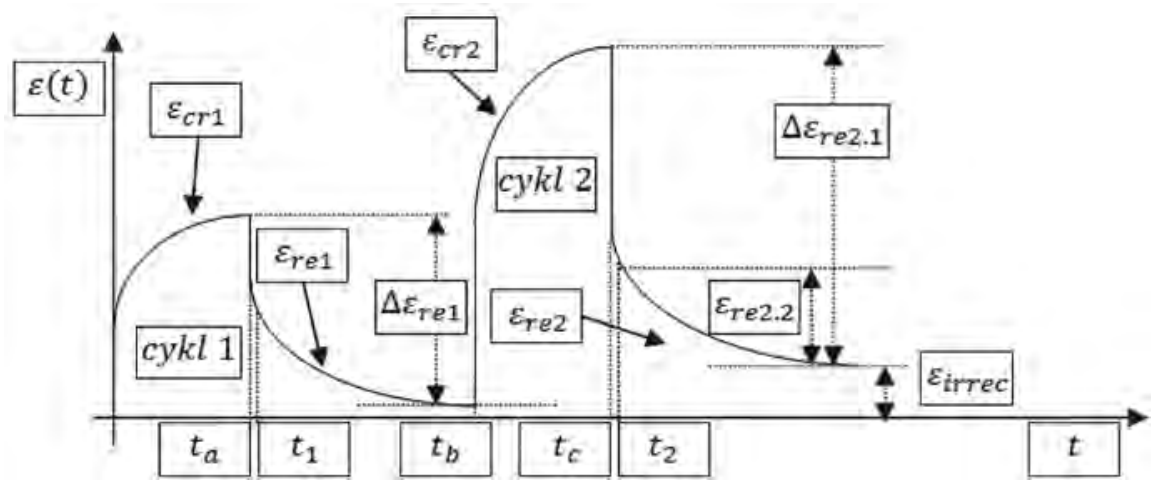

Fig. 2. Creep test with relief for two load cycles

Rys. 2. Schemat próby petzania z odciążeniem dla dwóch cyklów obciążenia

In order to determine all non-linear parameters, elastic recovery phase should be divided into two parts $[12,18]$. Parameters $g_{2}$ and $a_{\sigma}$ can be determined in the phase $\Delta \varepsilon_{\text {re2.2 }}=\varepsilon_{\text {re2 }}\left(t_{2}\right)-\varepsilon_{\text {re2 }}(t)$ while $g_{0}, g_{1}$, in the phase $\Delta \varepsilon_{r e 2.1}=\varepsilon_{r e 2}(t)-\varepsilon_{r e 2}(t)$. Including the stress history for subsequent load cycles leads to increasingly complicated equation (5). Therefore, the entire analysis was performed using the author's macroscript entered into the Mathcad program. The work presents a similar process [12].

\section{RESULTS}

Using the MSCR methodology in a slightly modified form, the course of stress versus time was obtained for three stress levels. The purpose of this procedure was to find non-linear parameters of the Schapery model. Thanks to this it is possible to determine the creep process in the axial system for any stress in the
Aby wyznaczyć wszystkie parametry nieliniowe należy fazę nawrotu sprężystego podzielić na dwie części $[12,18]$. Parametry $g_{2}$ oraz $a_{\sigma}$ można wyznaczyć w fazie $\Delta \varepsilon_{r e 2.2}=\varepsilon_{r e 2}\left(t_{2}\right)-\varepsilon_{r e 2}(t)$ natomiast $g_{0}, g_{1}$, w fazie $\Delta \varepsilon_{r e 2.1}=\varepsilon_{r e 2}(t)-\varepsilon_{r e 2}(t)$. Uwzględnienie historii naprężenia dla kolejnych cykli obciążenia powoduje że równanie (5) ma coraz to bardziej skomplikowaną postać. Dlatego też całą analizę wykonano przy pomocy autorskiego makroskryptu wprowadzonego w programie Mathcad. Podobny proces postępowania można odnaleźć w pracy [12].

\section{REZULTATY}

Wykorzystując metodykę MSCR w postaci nieco zmodyfikowanej uzyskano przebieg naprężenia względem czasu dla trzech poziomów naprężenia. Celem takiego postępowania było znalezienie parametrów nieliniowych modelu Schapery'ego. Dzięki temu możliwe jest określenie procesu pełzania $\mathrm{w}$ 
a)

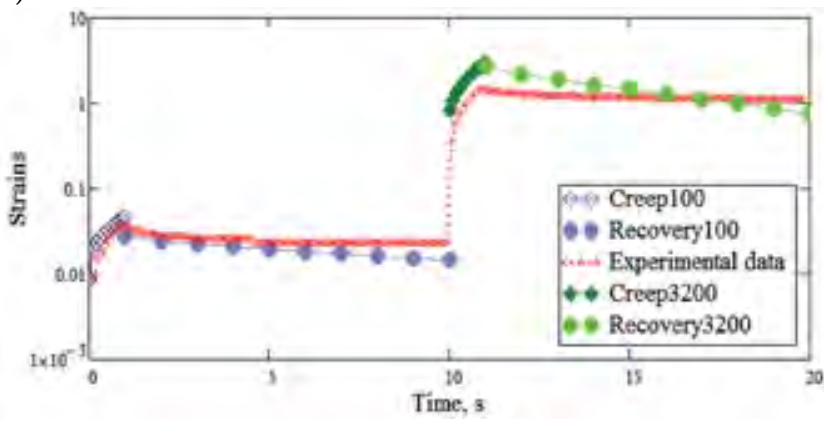

b)

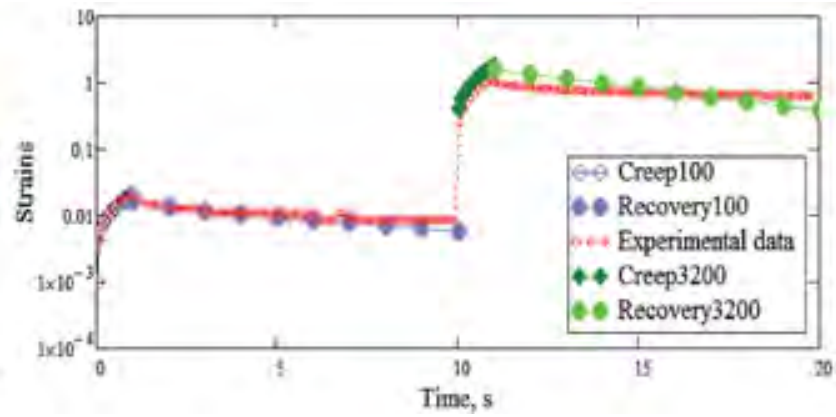

Fig. 3. Results of the model result matching to the experimental results for the composition: a) 0HL/FB2 for two load cycles (100 Pa and $3200 \mathrm{~Pa}$ ); b) 0.15HL/FB2 for two load cycles (100 Pa and $3200 \mathrm{~Pa}$ )

Rys. 3. Rezultaty dopasowania wyników modelu do rezultatów eksperymentalnych dla kompozycji: a) $0 H L / F B 2$ dla dwóch cykli obciążenia (100 Pa oraz 3200 Pa); b) 0,15HL/FB2 dla dwóch cykli obciażenia (100 Pa oraz 3200 Pa)

$0<\tau<6400 \mathrm{~Pa}$ range. The $50 / 70$ base asphalt was not tested at a stress of $6400 \mathrm{~Pa}$ due to its highly adhesive character preventing correct measurement of strain at a given rheometer measuring system. Therefore, the experimental results of the 50/70 asphalt strain were projected in relation to the model results of subsequent mastic compositions. The figure shows the results for the third load cycle (Figure 3).

Results of the model result matching to the experimental results for the case $0 \mathrm{HL} / \mathrm{FB} 2$ and $0.15 \mathrm{HL} / \mathrm{FB} 2$ determined on the basis of the formulas (4) and (5) are shown in Table 3. układzie osiowym dla dowolnego naprężenia w przedziale $0<\tau<6400 \mathrm{~Pa}$. Asfalt bazowy 50/70 nie został poddany badaniu przy naprężeniu $6400 \mathrm{~Pa} \mathrm{z}$ uwagi na jego wysoce lepki charakter uniemożliwiający poprawny pomiar odkształcenia w układzie pomiarowym reometru płytka-płytka $25 \mathrm{~mm}$. Dlatego też wyniki eksperymentalne odkształcenia asfaltu $50 / 70$ były rzutowane względem rezultatów modelowych późniejszych kompozycji mastyksu. Na rysunku 3 przedstawiono rezultaty dla trzeciego cyklu obciążenia.

Rezultaty dopasowania wyników modelowych do eksperymentalnych dla przypadków 0HL/FB2 oraz $0,15 \mathrm{HL} / \mathrm{FB} 2$, określonych na podstawie wzorów (4) oraz (5), przedstawiono w tabeli 3.

Table 3. Parameters of the linear and non-linear viscoelasticity model

Tabela 3. Parametry modelu liniowej i nieliniowej lepkosprężystości

Parameters for the linear viscoelasticity (LVE) range for the creep function consistent with the GK-H model for four Prony series elements

\begin{tabular}{|c|c|c|c|c|c|}
\hline \multicolumn{4}{|c|}{ Compliance } & \multicolumn{2}{|c|}{ Retardation time } \\
\hline \multicolumn{2}{|c|}{$\mathrm{J}_{0}$ (independent of time) } & \multicolumn{2}{|c|}{$\mathrm{J}_{\mathrm{i}}$ (independent of time) } & \multicolumn{2}{|c|}{$\lambda_{i}$} \\
\hline \multicolumn{2}{|c|}{$\left[\mathrm{Pa}^{-1}\right]$} & \multicolumn{2}{|c|}{$\left[\mathrm{Pa}^{-1}\right]$} & \multicolumn{2}{|c|}{$\left[s^{-1}\right]$} \\
\hline $\mathrm{OHL} / \mathrm{FB} 2$ & $0.15 \mathrm{HL} / \mathrm{FB} 2$ & OHL/FB2 & $0.15 \mathrm{HL} / \mathrm{FB} 2$ & OHL/FB2 & $0.15 \mathrm{HL} / \mathrm{FB} 2$ \\
\hline $9.995 \cdot 10^{-6}$ & $8.726 \cdot 10^{-5}$ & $\begin{array}{l}J_{1}=8.726 \cdot 10^{-5} \\
J_{2}=8.726 \cdot 10^{-5} \\
J_{3}=8.726 \cdot 10^{-5} \\
J_{4}=4.767 \cdot 10^{-3}\end{array}$ & $\begin{array}{l}J_{1}=19 \cdot 10^{-6} \\
J_{2}=22.597 \cdot 10^{-6} \\
J_{3}=442.883 \cdot 10^{-6} \\
J_{4}=1.096 \cdot 10^{-6}\end{array}$ & $\begin{array}{l}\lambda_{1}=1 \cdot 10^{-4} \\
\lambda_{2}=1.511 \\
\lambda_{3}=18.963 \\
\lambda_{4}=18.693\end{array}$ & $\begin{array}{l}\lambda_{1}=1 \cdot 10^{-9} \\
\lambda_{2}=0.1 \\
\lambda_{3}=8.067 \\
\lambda_{4}=10.069\end{array}$ \\
\hline
\end{tabular}

Parameters for the linear viscoelasticity (N-LVE) range for the creep function consistent with the GK-H model for four Prony series elements

\begin{tabular}{|c|c|c|c|c|c|c|}
\hline & \multicolumn{2}{|c|}{$\mathrm{T}=100 \mathrm{~Pa}$} & \multicolumn{2}{|c|}{$\mathrm{\tau}=3200 \mathrm{~Pa}$} & \multicolumn{2}{|c|}{$\tau=6400 \mathrm{~Pa}$} \\
\hline & OHL/FB2 & $0.15 \mathrm{HL} / \mathrm{FB} 2$ & $\mathrm{OHL} / \mathrm{FB} 2$ & $0.15 \mathrm{HL} / \mathrm{FB} 2$ & $\mathrm{OHL} / F B 2$ & $0.15 \mathrm{HL} / \mathrm{FB} 2$ \\
\hline$g_{0}$ & 1 & 1 & 1.000 & 0.997 & 0.997 & 0.997 \\
\hline$g_{1}$ & 1 & 1 & 0.777 & 0.761 & 0.798 & 0.702 \\
\hline$g_{2}$ & 1 & 1 & 1.374 & 1.135 & 3.214 & 2.132 \\
\hline$a_{\sigma}$ & 1 & 1 & 0.403 & 0.350 & 0.574 & 0.31 \\
\hline$g_{1} g_{2}$ & 1 & 1 & 1.068 & 0.863 & 1.472 & 1.497 \\
\hline
\end{tabular}


It should be noted that the use of hydrated lime $(0.15 \mathrm{HL} / \mathrm{FB} 2)$ causes that the mastic made with it obtained lower compliance $J_{0}$ than the mastic without hydrated lime (0HL/FB2). This indicates that hydrated lime beneficially contributed to the increase of momentary elasticity in the mastic. Observing the results of individual compliance values of the Prony series, it can be noticed that despite the faster reaching of successive retardation times by the mastics with hydrated lime, it still maintains high stiffness. Thus, providing a low level of strain. When analysing the results of the mastic's sensitivity to the stress level in terms of non-linear parameters, it should be noted that the parameter $g_{0}$ remains at a constant level regardless of the level of stress. Which indicates that the immediate compliance did not change as a result of increased stress. The parameter $g_{1}$ is responsible for the nonlinearity of the time-dependent compliance. The higher the value of the parameter $g_{1}$, the greater the probability of fast exceeding the flowing regime (the boundary between the second and third creep stage) and yielding of the sample. In addition, the increase in the $\mathrm{g}_{1}$ parameter in $0 \mathrm{HL} / \mathrm{FB} 2$ suggests an increase in mastic compliance (decrease in stiffness). Unfortunately, at this stage of the analysis, the yielding strength and its parameters have not been determined. Nevertheless, works are ongoing to determine the $\sigma-\varepsilon$ relationship that also takes into account the state at with the mastic yielding. With regard to the experiment performed, this value was reduced after the addition of hydrated lime $(0.15 \mathrm{HL} /$ FB2). Nonetheless, the value of the parameter $g_{2}$ that was dependent on the rate of stress growth, has dropped. The product $g_{1} g_{2}$ determines the vertical shift of the strain plot over time in relation to the LVE range. In this case, the presence of hydrated lime reduces the compliance quicker (high level $g_{1}$ $g_{2}$ ) than when the mastic was made of lime filler. In addition, the parameter $a_{\sigma}$ accounts for the horizontal shift of the plot $\varepsilon(t)$ in the N-LVE range in relation to the LVE range. Comparing the results of the coefficient $a_{\sigma}$ for both mastic compositions, it should be stated that the addition of hydrated lime reduces the time when the material's response is purely elastic. Thereby, the creep process will be faster than in the case of compositions without hydrated lime. Nevertheless, the low level of nonlinearity $g_{1}$ and the low compliance of each element of the Prony series makes the mastic with hydrated lime still maintain high stiffness despite the slightly
Należy zwrócić uwagę, że zastosowanie wapna hydratyzowanego $(0,15 \mathrm{HL} / \mathrm{FB} 2)$ powoduje, że wykonany z jego udziałem mastyks uzyskał niższą podatność $J_{0}$ niż mastyks bez wapna hydratyzowanego (0HL/FB2). Świadczy to o tym, że wapno hydratyzowane korzystnie przyczyniło się do wzrostu sprężystości chwilowej w mastyksie. Obserwując wyniki poszczególnych wartości podatności szeregu Prony'ego można zauważyć, że pomimo szybszego tempa osiągania przez mastyks z wapnem hydratyzowanym kolejnych czasów retardacji wciąż utrzymuje wysoką sztywność. Zapewniając tym samym niski poziom deformacji. Analizując wyniki wrażliwości mastyksu na poziom naprężenia w ujęciu nieliniowych parametrów, należy zwrócić uwagę, że parametr $g_{0}$ pozostaje na niezmiennym poziomie bez względu na poziom naprężenia. Co świadczy, że podatność natychmiastowa nie uległa zmianie na wskutek wzrostu naprężenia. Parametr $g_{1}$ jest odpowiedzialny za nieliniowość części podatności zależnej od czasu. Im większa wartość parametru $g_{1}$, tym większe prawdopodobieństwo szybkiego osiągnięcia przekroczenia stanu ustalonego płynięcia (granica pomiędzy II i III etapem pełzania) i uplastycznienia próbki. Ponadto wzrost parametru $g_{1}$ w 0 HL/FB2 sugeruje wzrost podatności (spadek sztywności mastyksu). Niestety na tym etapie analizy nie ustalono wartości granicy plastyczności oraz jej parametrów. Niemniej jednak wciąż trwają prace nad ustaleniem relacji $\sigma-\varepsilon$ uwzględniającej również stan uplastycznienia mastyksu. W odniesieniu do wykonanego eksperymentu wartość ta uległa korzystnemu zmniejszeniu po dodaniu wapna hydratyzowanego $(0,15 \mathrm{HL} / \mathrm{FB} 2)$. Spadkowi uległa także wartość parametru $g_{2}$, który jest zależny od tempa wzrostu naprężenia i reguluje wartość szybkości procesu relaksacji. Iloczyn $g_{1} g_{2}$ stanowi o pionowym przesunięciu wykresu odkształcenia w czasie względem zakresu LVE w fazie pełzania. W tym przypadku obecność wapna hydratyzowanego powoduje, że podatność będzie ulegała szybszej redukcji (wysoki poziom $g_{1} g_{2}$ ) niż w sytuacji, gdy mastyks został wykonany $\mathrm{z}$ wypełniacza wapiennego. Ponadto parametr $a_{\sigma}$ jest odpowiedzialny za poziome przesunięcie przebiegu wykresu $\varepsilon(t)$ w zakresie N-LVE w odniesieniu do zakresu LVE. Porównując wyniki współczynnika $a_{\sigma}$ dla obydwu kompozycji mastyksu, należy stwierdzić, że dodatek wapna hydratyzowanego powoduje skrócenie czasu, gdzie odpowiedź materiału ma charakter czysto sprężysty. Tym samym proces pełzania będzie postępował szybciej niż w przypadku kompozycji bez wapna hydratyzowanego. Niemniej jednak niski poziom nieliniowości $g_{1}$ oraz niska podatność każdego z elemen- 
faster rate of the creep process. The lower rate of elastic recovery of $0.15 \mathrm{HL} / \mathrm{FB} 2$ compared to $0 \mathrm{HL} /$ FB2 was compensated with a lower decrease in mastic stiffness in the creeping phase (expressed by lower value of $g_{1}$ ). It should be emphasized that the total elastic recovery is not possible to evaluate within 9 seconds.

To compare the results of the creep process of both mastic compositions, a numerical algorithm developed on the basis of the equation (1) using all the experimentally determined non-linear parameters of the Schapery model, was applied. Taking into account the basic recursive-iterative algorithm of Haj-Ali and Mulian [19] and the sub-integral creep function of the GK-H model, the strain increment value was determined on the basis of the formula:

$$
\begin{array}{r}
\Delta \gamma(t)=\left\{g_{0} J_{0}+g_{1} g_{2} \sum_{i=1}^{n} J_{i}\left[\frac{\Delta \psi}{\lambda_{i}}\left[e^{\left(-\lambda_{i} \Delta \psi\right)}-1\right]+1\right]\right\} \\
\Delta \sigma+\left\{\sum_{i=1}^{n} e^{\left(-\lambda_{i} \Delta \psi\right)}-1\right\} \gamma^{i}(t-\Delta t)
\end{array}
$$

where: $\Delta_{\sigma}-$ stress increment, $\Delta t-$ time increment, $\gamma^{i}(t-\Delta t)-$ strain caused by i-th element of the Prony series in time $(t-\Delta t)$. Simulation of material responses was performed for the stress history in sequence. The results of the numerical analysis are presented in the Figure. tów szeregu Prony'ego sprawia, że mastyks z wapnem hydratyzowanym będzie wciąż zachowywał wysoką sztywność, pomimo nieznacznie szybszego tempa procesu pełzania. Niższa szybkość nawrotu sprężystego mastyksu 0,15HL/FB2 w porównaniu do 0HL/FB2 była kompensowana $\mathrm{z}$ niższym spadkiem sztywności w fazie pełzania. Należy podkreślić, że całkowity nawrót sprężysty nie jest możliwy w czasie $9 \mathrm{~s}$.

Aby porównać rezultaty procesu pełzania obu kompozycji mastyksu, zastosowano algorytm numeryczny, opracowany na podstawie równania (1), wykorzystujący wszystkie eksperymentalnie ustalone parametry modelu nieliniowej lepkosprężystości Schapery'ego. Uwzględniając podstawowy rekursywno-iteracyjny algorytm Haj-Ali oraz Muliana [19] oraz uwzględniając podcałkową funkcję pełzania modelu GK-H, wartość przyrostu deformacji określono na podstawie formuły:

$$
\begin{gathered}
\Delta \gamma(t)=\left\{g_{0} J_{0}+g_{1} g_{2} \sum_{i=1}^{n} J_{i}\left[\frac{\Delta \psi}{\lambda_{i}}\left[e^{\left(-\lambda_{i} \Delta \psi\right)}-1\right]+1\right]\right\} \\
\Delta \sigma+\left\{\sum_{i=1}^{n} e^{\left(-\lambda_{i} \Delta \psi\right)}-1\right\} \gamma^{i}(t-\Delta t)
\end{gathered}
$$

gdzie: $\Delta_{\sigma}-$ przyrost naprężenia, $\Delta t$ - przyrost czasu, $\gamma^{i}(t-\Delta t)$-odkształcenie wywołane i-tym elementem szeregu Prony'ego w czasie $(t-\Delta t)$. Symulację odpowiedzi materiałów wykonano dla historii naprężenia w sekwencji. Rezultaty analizy numerycznej przedstawiono na rysunku 4.

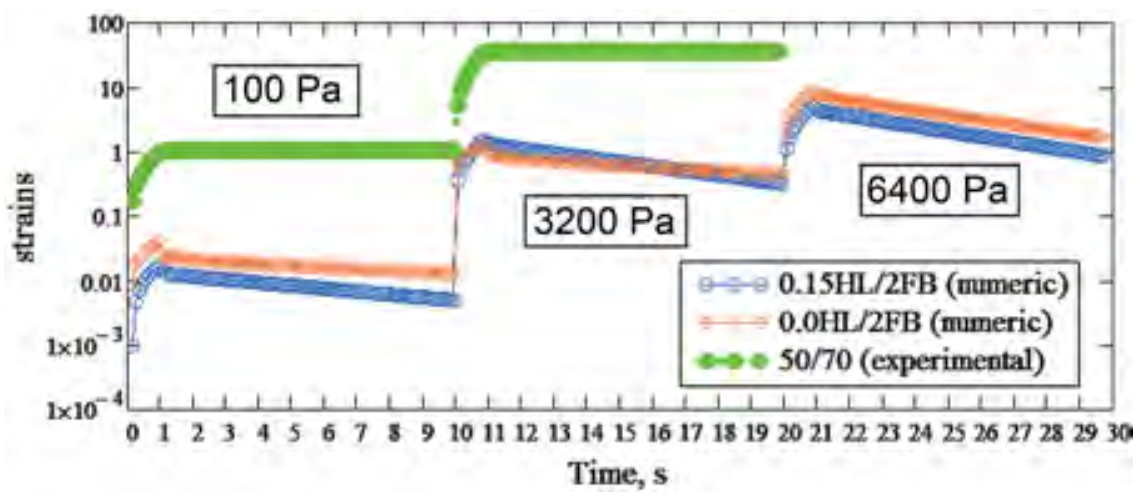

Fig. 4. Numerical analysis of the course $\varepsilon(t))$ depending on the stress cycle Rysunek 4. Analiza numeryczna przebiegu $\varepsilon(t) w$ zależności od cyklu naprężenia

When analysing the test results in Figure 4, it should be noted that the 50/70 asphalt indicates no elastic recovery in the relief cycle at a temperature of $60^{\circ} \mathrm{C}$ for $100 \mathrm{~Pa}$ and $3200 \mathrm{~Pa}$. This means that the asphalt behaves similar to the Newtonian fluid. In the case of the $0.15 \mathrm{HL} / \mathrm{FB} 2$ mastic, a clearly lower
Analizując wyniki badań na rysunku 4 ,należy zwrócić uwagę, że asfalt $50 / 70 \mathrm{w}$ temperaturze $60^{\circ} \mathrm{C}$ dla naprężenia $100 \mathrm{~Pa}$ oraz $3200 \mathrm{~Pa}$ wskazuje na brak nawrotu sprężystego w cyklu odciążenia. Oznacza to, że asfalt zachowuje się podobnie do cieczy newtonowskiej. W przypadku mastyksu $0,15 \mathrm{HL} / \mathrm{FB} 2$ widać 
compliance in each of the load cycles in relation to the $0 \mathrm{HL} / \mathrm{FB} 2$ composition can be seen. Therefore, it should be stated that the presence of hydrated lime has an effect on minimizing the mastic strain process. In addition, the largest elastic recovery in the mastic with hydrated lime was observed. This is extremely important from the point of view of the hydrated lime implementation in the asphalts, because the increase in strain in asphalt by $1 \%$ increases strain in the binder by up to $46 \%$ [20].

\section{CONCLUSIONS}

The following conclusions were made based on the performed tests and analyses:

- description of the mastic, using a non-linear viscoelasticity model, characterizes, in a comprehensive manner, the behaviour of the material, functionally binding load time, temperature and stress,

- the mastic containing hydrated lime obtained the lowest instantaneous compliance $J_{0}$. This is reflected in the high stiffness of the mastic with hydrated lime,

- in the mastic with hydrated lime, the value of the parameter $\mathrm{g}_{1}$ that is responsible for the non-linearity of the compliance part, which is time dependent, was the lowest. As a result, the mastic with hydrated lime will probably reach the third creep stage in the higher stress range than the mastic with lime filler,

- the highest value of the product $g_{1} g_{2}$ (proportional strain increment) was noted for the mastic with limestone filler. Nevertheless, the stiffness of the mastic with hydrated lime, from the fact of the low value of parameter $g_{1}$, is higher than the mastic with the addition of limestone (mineral) filler,

- The highest elastic recovery, based on the numerical analysis, was recorded for the composition of the mastic with hydrated lime,

- the use of hydrated lime in the mastic has a significant effect on reducing strain over time. wyraźnie niższą podatność w każdym z cykli obciążenia w stosunku do kompozycji 0HL/FB2. W związku z tym należy stwierdzić, że obecność wapna hydratyzowanego korzystnie wpływa na minimalizację procesu deformacji mastyksu. Ponadto zaobserwowano największy nawrót sprężysty $\mathrm{w}$ mastyksie z wapnem hydratyzowanym. Ma to ogromne znaczenie $\mathrm{z}$ punktu widzenia implementacji wapna hydratyzowanego do mieszanek mineralno-asfaltowych, gdyż wzrost odkształcenia w mma o $1 \%$ powoduje wzrost odkształcenia w lepiszczu nawet o 46\% [20].

\section{WNIOSKI}

Na podstawie wykonanych badań i analiz sformułowano następujące wnioski:

- opis mastyksu za pomocą modelu nieliniowej lepkosprężystości w sposób kompleksowy charakteryzuje zachowanie materiału, wiążąc funkcyjnie czas obciążenia, temperaturę oraz naprężenie,

- mastyks zawierający wapno hydratyzowane uzyskał najniższą podatność chwilową $J_{0}$. Ma to odzwierciedlenie w dużej sztywności mastyksu z wapnem hydratyzowanym,

- w mastyksie $\mathrm{z}$ wapnem hydratyzowanym wartość parametru $g_{1}$ odpowiedzialnego za nieliniowość części podatności, która jest zależna od czasu, była najniższa. W rezultacie mastyks $\mathrm{z}$ wapnem hydratyzowanym prawdopodobnie osiągnie III etap pełzania $\mathrm{w}$ zakresie większych naprężeń niż mastyks $\mathrm{z}$ wypełniaczem wapiennym,

- najwyższą wartość iloczyny $g_{1} g_{2}$ (proporcjonalny przyrost deformacji) odnotowano dla mastyksu z mączką wapienną. Pomimo tego sztywność mastyksu $\mathrm{z}$ wapnem hydratyzowanym jest wyższa $\mathrm{z}$ faktu niskiej wartości parametru $g_{1}$ niż z dodatkiem wypełniacza mineralnego,

- na podstawie analizy numerycznej najwyższy korzystny nawrót sprężysty został zarejestrowany dla kompozycji mastyksu z wapnem hydratyzowanym,

- zastosowanie wapna hydratyzowanego w mastyksie ma istotny wpływ na ograniczenie deformacji w czasie.

\section{REFERENCES}

[1] „Katalog typowych konstrukcji nawierzchni podatnych i półsztywnych”. 2014.

[2] Obara P. i Gilewski W., ,Dynamic stability of moderately thick beams and frames with the use of harmonic balance and perturbation methods", Bulletin of the Polish Academy of Sciences Technical Sciences, t. 64, nr 4, 2016.

[3] Kim Y. R., Red., Modeling of asphalt concrete. Reston, VA : New York: ASCE Press; McGraw-Hill, 2009.

[4] Mazurek G. i Iwański M., ,Relaxation Modulus of SMA with Polymer Modified and Highly Polymer Modified Bitumen”, Procedia Engineering, t. 172, s. 731-738, 2017. 
[5] Klabińska M. i Piłat J., Reologia asfaltów i mas mineralno-asfaltowych. WKŁ, 1982.

[6] Bonaquist R.F., Refining the simple performance tester for use in routine practice. Washington, D.C: Transportation Research Board, 2008.

[7] Chailleux E., Ramond G., Such C., i de La Roche C., „A mathematical-based master-curve construction method applied to complex modulus of bituminous materials", Road Materials and Pavement Design, t. 7, nr sup1, s. 75-92, 2006.

[8] Schapery R. A., „On the characterization of nonlinear viscoelastic materials”, Polymer Engineering and Science, t. 9, nr 4, s. 295-310, 1969.

[9] Zhang Y., Luo R., i Lytton R. L., „Characterization of viscoplastic yielding of asphalt concrete”, Construction and Building Materials, t. 47, s. 671-679, 2013.

[10] Brinson H. F. i Brinson L. C., Polymer engineering science and viscoelasticity: an introduction. New York: Springer, 2008.

[11] Shirodkar P., Mehta Y., Nolan A., Dahm K., Dusseau R., i McCarthy L., „Characterization of creep and recovery curve of polymer modified binder", Construction and Building Materials, t. 34, s. 504-511, 2012.

[12] Huang C.W., Abu Al-Rub R. K, Masad E. A., Little D. N., i Airey G. D., „Numerical implementation and validation of a nonlinear viscoelastic and viscoplastic model for asphalt mixes", International Journal of Pavement Engineering, t. 12, nr 4, s. 433-447, 2011.

[13] Grabowski W., Struktura a właściwości funkcjonalne wypełniaczy mineralnych stosowanych w drogownictwie. Poznań: Wydawnictwo Politechniki Poznańskiej, 2007.

[14] Lesueur D., Petit J., i Ritter H.J., ,The mechanisms of hydrated lime modification of asphalt mixtures: a state-of-theart review", Road Materials and Pavement Design, t. 14, nr 1, s. 1-16, 2013.

[15] Grabowski W. i Wilanowicz J., ,The structure of mineral fillers and their stiffening properties in filler-bitumen mastics", Materials and Structures, t. 41, nr 4, s. 793-804, 2008.

[16] Schapery R. A., A Theory of Non-linear Thermoviscoelasticity Based on Irreversible Thermodynamics. American Society of Mechanical Engineers, 1966.

[17] Schapery R. A., „An engineering theory of nonlinear viscoelasticity with applications”, International Journal of Solids and Structures, t. 2, nr 3, s. 407-425, 1966.

[18] J. Lai i A. Bakker, „An integral constitutive equation for nonlinear plasto-viscoelastic behavior of high-density polyethylene", Polymer Engineering and Science, t. 35, nr 17, s. 1339-1347, 1995.

[19] Haj-Ali R. M. i Muliana A. H., „Numerical finite element formulation of the Schapery non-linear viscoelastic material model", International Journal for Numerical Methods in Engineering, t. 59, nr 1, s. 25-45, 2004.

[20] Kose S., Guler M., Bahia H., i Masad E., „Distribution of Strains Within Hot-Mix Asphalt Binders: Applying Imaging and Finite-Element Techniques", Transportation Research Record: Journal of the Transportation Research Board, t. 1728, s. 21-27, 2000.

\section{Acknowledgments:}

The work was financed by Kielce University of Technology, part of the statutory work No. 02.0.09.00/2.01.01.01.0000 MNSP.BKIK.18.002

\section{Podziękowania:}

Praca byta finansowana przez Politechnikę Świętokrzyska, w ramach pracy statutowej $n r: 02.0 .09 .00 / 2.01 .01 .01 .0000$ MNSP.BKIK.18.002 